\title{
Artikel
}

\section{Enkele opmerkingen over de invoering van de Curaçaose Landsverordening inzake Concurrentie en de instelling van een Curaçaose mededingingsautoriteit}

Sjoerd Bakker*

\section{Inleiding}

Introductie

Per 1 september 2017 is de Landsverordening inzake Concurrentie (Landsverordening Concurrentie) in werking getreden. De door deze Landsverordening in het leven geroepen Fair Trade Authority Curaçao (FTAC) oefent sinds die datum haar toezichthoudende taken uit, als beschreven en omlijnd in diezelfde Landsverordening. Daarmee is Curaçao in de voetsporen getreden van meerdere andere kleine (ei)landen in de Caribische regio, die eveneens mededingingswetgeving kennen, op de naleving waarvan door een mededingingsautoriteit wordt toegezien. Onder meer Barbados, Jamaica en de Bahama's gingen Curaçao op dit punt voor. ${ }^{1}$

Plan van behandeling/leeswijzer

Deze bijdrage beoogt een introductie te geven van het Curaçaose mededingingsrecht. In deze bijdrage zal achtereenvolgens worden stilgestaan bij (1) de achtergronden voor invoering van genoemde Landsverordening op Curaçao en de vraag in hoeverre kleinere jurisdicties als

Mr. dr. P.S. Bakker is werkzaam bij Spigt Dutch Caribbean en tevens verbonden aan de Vrije Universiteit Amsterdam. De auteur dankt mr. S. Tuinenga en prof. mr. L.J.J. Rogier voor hun advies en commentaar op een eerdere versie van dit artikel. Dit artikel zal, in iets gewijzigde vorm, binnenkort eveneens worden geplaatst in Caribisch Juristenblad.

1. Zie nader <www.caricomcompetitioncommission.com/en/competition $>$. die van Curaçao (überhaupt) regels nodig hebben die de economische mededinging reguleren en aan banden leggen, (2) de belangrijkste verschillen en overeenkomsten tussen de Landsverordening Concurrentie en de Nederlandse Mededingingswet (Mw) en (3) de vraag hoe de publiek- en privaatrechtelijke handhaving van de nieuwe Landsverordening eruit zal (kunnen gaan) zien.

\section{Achtergronden}

\section{'Standard notions of competition may not work'} Dat ook kleine jurisdicties behoefte kunnen hebben aan regulering van de mededinging is geen nieuw inzicht. Zo'n veertig jaar geleden betoogde Ransom al eens dat juist in kleine economieën, zoals die in de Caribische regio veel voorkomen, het risico van ontoereikende mededinging reëel te noemen is:

'In a smaller economy, however, particularly one dependent on imported necessities, the small scale can magnify imperfect competition, and a monopoly can be more quickly formed and entrenched. Certain facets of some island economies, for example, are controlled by the remains of old plantocracies. These, in some cases, have evolved into vertically-integrated 
distributional monopolies, either over desirable brand names or over a type of commodity.'2

Ransom wees erop dat de bijzondere omstandigheden op het gebied van vraag en aanbod in kleine economieen, zoals die in de Caribische regio veel voorkomen, met zich brengen dat 'standard notions of competition may not work':3

'The buying power of the community may be so small that attempts by government regulation to force a product or brand to be distributed by more than one outlet may be counterproductive, forcing several companies to invest in the purchase of independent supplies of the same item, thus causing an overall excessive supply. This will mean that the items will not sell as fast as they should; money will be tied up for too long; there will be a need for larger profit margins on fewer items sold on longer-term financing; and the result will be higher, rather than lower, consumer prices as a result of enforced, artificial competition. ${ }^{4}$

Anders gezegd: regulering van de mededinging in kleinere economieën is evenzeer als in grote(re) economieën noodzakelijk, maar daarbij moet wel met de specifieke kenmerken $^{5}$ en omstandigheden van dergelijke kleine economieën rekening worden gehouden; 'maatwerk' is derhalve het devies. In zijn artikel wees Ransom destijds naar CARICOM (Caribbean Community) als 'ideal vehicle' om regulering van de mededinging in de Caribische regio vorm te gaan geven.

\section{CARICOM en het Herziene Verdrag van \\ Chaguaramas}

Ransoms wensen op dit punt zijn uitgekomen. CARICOM is, zoals hierna zal blijken, inderdaad de voortrekker gebleken van (de ontwikkeling van) een Caribisch mededingingsbeleid. CARICOM is de Caribische tegenhanger van de Europese Unie en werd in het leven geroepen door ondertekening van het Verdrag van Chaguaramas op 4 juli 1973. Het verdrag werd destijds gete-

2. A.A. Ransom, 'The Need for Antitrust Laws in the Caribbean and Their Actual or Possible Impact on Trade', Maryland Journal of International Law 1978, 4(1), te vinden op: <http://digitalcommons.law.umaryland. edu/mjil/vol4/iss1/21>. Zie in dezelfde zin de MvT, Staten van Curaçao, zitting 2014/15, Landsverordening houdende vaststelling van de Landsverordening inzake concurrentie, nr. 3, p. 3. Zie voorts onder meer de OECD-notitie 'Competion Policy and Small Economies' (CCNM/GF/COMP(2003)5 uit 2003 (te vinden op <www.oecd.org/ daf/competition/prosecutionandlawenforcement/2486724.pdf $>$ ) alsmede het uit 2009 daterende ICN Special Project Report for the 8th Annual Conference Competition Law in Small Economies (te vinden op $<$ www.internationalcompetitionnetwork.org/uploads/library/doc385. $\mathrm{pdf}>$ ).

3. Ransom 1978, p. 113.

4. Ransom 1978, p. 113.

5. Een van die kenmerken is bijvoorbeeld de beperkte exportkracht van Caribische landen, die kan aanzetten tot kartelvorming. In de woorden van Ransom (Ransom 1978, p. 116): '(...) no one nation can export enough of anything to significantly affect world markets or market prices. In other words, output is simply too small to make a dent in anything. This is so, for example, even with respect to bauxite in Jamaica or oil in Venezuela. Theoretically, the simple answer is to cartelize.' kend door Barbados, Guyana, Jamaica en Trinidad en Tobago. Het verdrag leidde tot de oprichting van een 'Caribbean Single Market and Economy' (CSME) en verving daarmee de zogeheten 'Caribbean Free Trade Association', die op 1 mei 1974 ophield te bestaan. Evenals de Europese Unie is CARICOM in de loop van de decennia flink uitgebreid; inmiddels telt CARICOM vijftien lidstaten.

In 2001 volgde het Herziene Verdrag van Chaguaramas, dat een apart hoofdstuk (Hoofdstuk 8) met mededingingsregels kent en tevens voorziet in de oprichting van de CARICOM-Commissie voor de Mededinging. Deze Commissie heeft als voornaamste doel het handhaven van de CARICOM-mededingingsregels, zoals deze in het Herziene Verdrag zijn neergelegd. De Commissie is geinstalleerd in 2008, bestaat uit zeven leden en is gezeteld in Paramaribo, Suriname. Evenals de Europese Commissie heeft de CARICOM-Commissie voor de Mededinging ruime bevoegdheden tot het doen van onderzoek naar mogelijke schendingen van mededingingsregels en de mogelijkheid tot het treffen van sancties tegen ondernemingen die zich schuldig maken aan de uitschakeling, beperking of vervalsing van de mededinging.

\section{Een eigen Curaçaos mededingingsbeleid} Curaçao is geen lidstaat (maar enkel waarnemend lid) van CARICOM en daarmee niet alleen onttrokken aan de werking van de genoemde mededingingsregels die in het Herziene Verdrag zijn neergelegd, maar ook aan de in artikel 170 van het Herziene Verdrag neergelegde verplichting voor de CARICOM-lidstaten tot het bij wet invoeren van (met het Herziene Verdrag congruerende) mededingingsregels en de verplichting tot het oprichten van een nationale mededingingsautoriteit die toeziet op naleving van bedoelde regels. Dat op Curaçao niettemin tot het invoeren van een dergelijke wet en oprichting van een dergelijke autoriteit is besloten, heeft blijkens de memorie van toelichting (MvT) bij de Landsverordening Concurrentie veel, zo niet alles, te maken met het hiervoor al genoemde besef dat in kleinere economieën, zoals die van Curaçao, het risico op 'marktverstoringen en marktimperfecties groter [is] dan in grotere economieën met grotere markten'. 6 Diezelfde MvT maakt duidelijk dat bij de wetgever op Curaçao de (begrijpelijke) wens voorlag om voor buitenlandse ondernemingen een aantrekkelijk(er) investeringsklimaat te scheppen en dit land in sync te brengen met de wereldwijd en ook in de regio sterk toenemende behoefte aan open en transparante (handels)markten, die gekenmerkt worden door een vrije en onbelemmerde mededinging. ${ }^{7}$

Aan het besluit van de Curaçaose wetgever is onderzoek naar de stand van de mededinging op Curaçao voorafgegaan, vergezeld van een zogeheten 'nulmeting' die in het

6. MvT, Staten van Curaçao, zitting 2014/15, Landsverordening houdende vaststelling van de Landsverordening inzake concurrentie, nr. 3, p. 3.

7. MvT, Staten van Curaçao, zitting 2014/15, Landsverordening houdende vaststelling van de Landsverordening inzake concurrentie, nr. 3, p. 2-3. 
jaar 2011 is uitgevoerd en betrekking had op een vijftal sectoren van de Curaçaose economie, te weten: (1) de groot- en detailhandel van levensmiddelen, (2) bancaire producten, (3) de bouw van infrastructurele projecten, (4) de import van geneesmiddelen, en (5) internet. Blijkens de MvT had de nulmeting een tweeledig karakter en omvatte deze een meting van

'de "harde" indicatoren (o.a. marktstructuur en marktuitkomsten) en een meting van de "zachte" indicatoren (percepties van consumenten). Voor de meting van de "harde" indicatoren is gebruikt gemaakt van gangbare en geaccepteerde maatstaven zoals de C-ratio en de Herfindahl-Hirschman Index (HHI). Deze parameters geven inzicht in de concentratie van markten aan de hand van het aantal aanbieders en hun respectievelijke marktaandeel. Voor de meting van de "zachte" indicatoren zijn consumenten ondervraagd over hun percepties ten aanzien van de kwaliteit van het product, het prijsniveau en de klantvriendelijkheid van de aanbieders in de desbetreffende markt. Deze meting kan herhaald worden om veranderingen in de tijd te registreren zodat de effectiviteit van het mededingingstoezicht bepaald kan worden. ${ }^{8}$

De Landsverordening, zoals deze er thans ligt, vloeit in belangrijke make voort uit het hiervoor bedoelde onderzoek en de gehouden nulmeting. ${ }^{9}$ Het ligt blijkens de MvT in de bedoeling om bij de evaluatie na vijf jaar (waarin art. 10.3 van de Landsverordening Concurrentie voorziet), tevens een meting te laten uitvoeren naar de effecten die de nieuwe regels en het optreden van de FTAC op de mededinging hebben gehad en wat de maatschappelijke baten daarvan zijn. In de MvT wordt verder aangegeven dat bij de inrichting van de Landsverordening beoogd is rekening te houden met de specifieke, door kleinschaligheid gekenmerkte, context van Curaçao. In hoeverre de Curaçaose wetgever in deze opzet is geslaagd, komt hierna aan de orde.

\section{De Landsverordening Concurrentie en de Nederlandse Mededingingswet vergeleken}

\section{Vertrouwde begrippen en normen}

Het eerste dat opvalt bij een vergelijking tussen de Landsverordening Concurrentie en de $\mathrm{Mw}$ is dat in de Landsverordening Concurrentie, evenals in de $\mathrm{Mw}$, aansluiting blijkt te zijn gezocht bij de bekende Europeesrechtelijke begrippen (zoals onderneming, overeenkomsten, besluiten, onderling afgestemde feitelijke

8. MvT, Staten van Curaçao, zitting 2014/15, Landsverordening houdende vaststelling van de Landsverordening inzake concurrentie, nr. 3, p. 4

9. Bij het ontwerp van het nieuwe mededingingsregime voor Curaçao zijn ook het Nederlandse ministerie van Economische Zaken alsmede de NMa (thans: de ACM) intensief betrokken geweest. gedragingen, concurrentiebeperkingen, misbruik en machtspositie) en het Europeesrechtelijke normenkader op het gebied van het mededingingsrecht. Blijkens de MvT is de reden daarvoor drieledig geweest.

De eerste reden is gelegen in de wens van de Curaçaose wetgever om aan te sluiten bij de interpretatiegeschiedenis van die begrippen en normen, zoals die in een jarenlange Europese mededingingsrechtelijke jurisprudentietraditie haar beslag heeft gekregen; de rechtszekerheid is er volgens de Curaçaose wetgever mee gediend dat met een begrippen- en normenkader wordt gewerkt waarvan de betekenis door jarenlange inkleuring en toenemende verfijning helder(der) is geworden. De tweede reden hangt met de vorige samen: het werken met dezelfde begrippen en normen als die reeds in het (sterk door het Europese mededingingsrecht beïnloede) Nederlandse mededingingsrecht worden gehanteerd, makt het de Hoge Raad als cassatierechter voor het gehele Koninkrijk denkelijk makkelijker om recht te spreken in kwesties rondom civiele aansprakelijkheid voor schending van het mededingingsrecht: 'gebruik van zeer vergelijkbare normen (zal) leiden tot efficiëntere rechtsbedeling en grotere rechtszekerheid'. ${ }^{10}$ De derde reden is dat hantering van op de $\mathrm{Mw}$ geënte mededingingsregels naar de verwachting van de Curaçaose wetgever bij zal dragen aan een goede uitwisseling en opleiding tussen Curaçao en Nederland. Aansluiting bij het vertrouwde begrippen- en normenkader van de Mw werkt efficiënte(re) samenwerking tussen beide landen in de hand, zowel op het gebied van handhaven als dat van rechtspreken, zo is de gedachte.

Opvallend genoeg mist in de Landsverordening of de toelichting daarop een expliciet interpretatie- en toepassingscriterium, dat duidelijk maakt hoe de Curaçaose Landsverordening zich (precies) verhoudt tot de Nederlandse en Europese mededingingsregels. Een Curaçaose pendant van het in de Nederlandse memorie van toelichting bij de Mw opgenomen 'niet strenger en niet soepeler'-principe ${ }^{11}$ ontbreekt, waardoor niet ondenkbaar te achten is dat de Curaçaose rechter in de toekomst op bepaalde punten op zeker moment een eigen 'lijn' zal gaan trekken c.q. zal gaan afwijken van de in Nederland en Europa vigerende uitleg en toepassing van

10. MvT, Staten van Curaçao, zitting 2014/15, Landsverordening houdende vaststelling van de Landsverordening inzake concurrentie, nr. 3, p. 7.

11. Kamerstukken // 1995/96, 24 707, nr. 3, p. 10. Vanuit een oogpunt van rechtseenheid en rechtszekerheid zou het denkelijk toe te juichen zijn als (een variant op) deze interpretatieregel ook met betrekking tot het Curaçaose mededingingsrecht toepassing zou (gaan) vinden, waardoor (ook met betrekking tot de hierna te noemen merkbaarheidseis) het Curaçaose mededingingsrecht in de pas zal gaan c.q. blijven lopen met de ontwikkelingen in Europa en Nederland. 
bepaalde mededingingsrechtelijke begrippen en normen. ${ }^{12}$

\section{Merkbaarheid}

Evenals in de Mw zijn in de Landsverordening Concurrentie de regels die het maken van mededingingsafspraken verbieden, ondergebracht in Hoofdstuk 3. Artikel 3.1 van de Landsverordening bepaalt:

'Verboden zijn overeenkomsten tussen ondernemingen, besluiten van ondernemersverenigingen en onderling afgestemde feitelijke gedragingen van ondernemingen, die ertoe strekken of ten gevolge hebben dat de concurrentie op de Curaçaose markt of een deel daarvan merkbaar wordt verhinderd, beperkt of vervalst.'

Opvallend verschil (voor het overige zijn beide bepalingen gelijkluidend) met artikel 6 lid $1 \mathrm{Mw}$ is het woord 'merkbaar'. Daarmee is gelijk al een controversieel punt aangeroerd. Het arrest Völk/Vervaecke ${ }^{13}$ uit 1969 leert dat het verbod van artikel 101 Verdrag betreffende de werking van de Europese Unie (VWEU) (voorheen art. 81 EG-Verdrag) niet van toepassing is op afspraken die de mededinging of de handel tussen de lidstaten niet merkbaar beperken. Algemeen werd nadien in de Nederlandse rechtspraak en literatuur aangenomen dat ook voor de toepassing van artikel $6 \mathrm{Mw}$ een zogeheten 'merkbaarheidsvereiste' gold, niet alleen bij afspraken die ten gevolge hebben dat de mededinging wordt beperkt, maar ook bij afspraken die de strekking hebben de mededinging te beperken. Het arrest Expedia ${ }^{14}$ van het Hof van Justitie heeft in dit kader enige beroering in de doctrine veroorzaakt. In dit uit 2012 daterende arrest oordeelde het Hof van Justitie in rechtsoverweging 37:

'Bijgevolg moet worden vastgesteld dat een overeenkomst die de handel tussen lidstaten ongunstig kan beïnvloeden en een mededingingsbeperkende strekking heeft, naar haar aard en los van elk concreet gevolg ervan een merkbare beperking van de mededinging vormt.'

Verschillende auteurs hebben erop gewezen dat deze overweging op meerdere wijzen kan worden geïnterpreteerd. Zo geeft Cornelissen ${ }^{15}$ aan dat onder meer moge-

12. In dit kader dient voorts te worden bedacht dat het mededingingsrecht voor een belangrijk deel bestuursrechtelijk van aard is. Het bestuursrecht valt evenwel buiten de reikwijdte van het in art. 39 Statuut voor het Koninkrijk der Nederlanden neergelegde concordantiebeginsel, waardoor op het gebied van bestuursrechtelijk mededingingsrecht geen verplichting bestaat tot concordantie van wetgeving of rechtspraak. Zie over het concordantiebeginsel nader L.J.J. Rogier, 'Het einde van het concordantiebeginsel?', RMThemis 2016/3, p. 124 e.v. en P.S. Bakker, 'De redelijkheid en billijkheid in art. 3:12 BW en het concordantiebeginsel', NTBR 2017, afl. 2, p. 49 e.v.

13. HvJ EG 9 juli 1969, zaak C-5/69, Völk/Vervaecke, ECLI:EU:C:1969:35

14. HvJ EU 13 december 2012, zaak C-226/11, Expedia, ECLI:EU:C: 2012:795, NJ 2013/253 m.nt. M.R. Mok. Zie over het arrest ook de conclusie van A-G Keus voor HR 24 januari 2014, ECLI:NL:HR: 2014:149, NJ 2016/489.

15. H.M. Cornelissen, 'Het Expedia-arrest: een merkbare koerswijziging?', NtEr 2013/5, p. 174. lijk is dat de bedoeling van het Hof van Justitie is geweest met die overweging aan te geven dat de merkbaarheid in geval van een strekkingsbeperking gegeven is, zonder dat daartoe nog een merkbaarheidstoets dient te worden uitgevoerd. Een andere, door Outhuijse geopperde mogelijke interpretatie is dat het Hof van Justitie met het arrest aan heeft willen geven dat de merkbaarheid bewezen dient te worden als onderdeel van de kwalificatietoets. In deze interpretatie valt de vraag of er sprake is van een strekkingsbeperking 'samen met de vraag of een overeenkomst de mededinging in voldoende mate, oftewel merkbaar, aantast. Indien de overeenkomst de mededinging niet in voldoende mate aantast kan deze geen strekkingsbeperking zijn (...). ${ }^{16}$

Nog een in de literatuur geopperde mogelijkheid is dat het Hof van Justitie duidelijk heeft willen maken dat bij strekkingsbeperkingen de bewijsplicht ten aanzien van de merkbaarheid niet meer geldt: bij een gedraging die een strekkingsbeperking vormt, zou in deze visie geen nader bewijs nodig zijn om aan het merkbaarheidsvereiste te voldoen. ${ }^{17}$

Inmiddels heeft het Hof van Justitie in de uitspraak Cartes Bancaires ${ }^{18}$ meer helderheid gegeven over de vraag hoe zijn uitspraak inzake Expedia dient te worden verstaan en heeft het bevestigd dat de vraag of er sprake is van een strekkingsbeperking inderdaad samenvalt met de vraag of een overeenkomst de mededinging in voldoende mate, oftewel merkbaar, aantast. ${ }^{19}$ De Hoge Raad volgt deze lijn inmiddels ook en oordeelde in het arrest HR 14 juli 2017, ECLI:NL:HR:2017:1354 recentelijk eveneens dat als eenmaal is vastgesteld dat van een mededingingsbeperkende strekking sprake is, de merkbaarheid niet meer afzonderlijk behoeft te worden onderzocht.

Door het woord 'merkbaar' aan de tekst van artikel 3.1 van de Landsverordening toe te voegen (de MvT spreekt van 'explicitering van het merkbaarheidsvereiste', zonder duidelijk te maken wat daarmee, mede in het licht van de hiervoor geschetste ontwikkelingen in de (Europese en Nederlandse) rechtspraak, wordt bedoeld), ${ }^{20}$ wekt de Curaçaose wetgever, wellicht onbedoeld, de suggestie dat bij strekkingsbeperkingen die onder de reikwijdte van het Curaçaose mededingingsrecht vallen, de merkbaarheid wel nog afzonderlijk getoetst zou moeten worden. Temeer daar de MvT bij de Landsverordening op dit punt geen (enkel) houvast biedt, is het afwachten hoe de Curaçaose civiele dan wel bestuursrechter met de merkbaarheidseis bij strekkingsbeperkingen in zijn rechtspraak om zal (blijken te) gaan. In dit kader is niet onbelangrijk dat de Curaçaose rech-

16. Aldus A. Outhuijse, 'Kroniek - Bestuurs- en civielrechtelijke rechtspraak mededingingsrecht 2016', SEW 2016/5, p. 202.

17. A. Outhuijse, 'Wat doet de Nederlandse rechter met het merkbaarvereiste na Expedia?', SEW 2014/9, p. 393.

18. HvJ EU 11 september 2014, zaak C-67/13 P, Cartes Bancaires, ECLI:EU:C:2014:2204

19. Aldus ook de conclusie van A-G De Bock (onder 3.6.9) voor HR 14 juli 2017, ECLI:NL:HR:2017:1354.

20. MvT, Staten van Curaçao, zitting 2014/15, Landsverordening houdende vaststelling van de Landsverordening inzake concurrentie, nr. 3, p. 40. 
ter, anders dan zijn Nederlandse collega die over mededingingskwesties rechtspreekt, geen verplichting heeft 'om in vrijwel elke zaak van betekenis artikel 101 of 102 VWEU toe te passen' ${ }^{21}$ en dus mogelijk minder druk dan zijn Nederlandse collega zal voelen om te voldoen aan het in Nederland vigerende convergentiebeginsel (dat inhoudt dat het nationale recht zo veel mogelijk in de geest van het Europese recht moet worden uitgelegd). ${ }^{22}$

\section{Per se-verboden}

De Curaçaose wetgever heeft er blijkens de Mv'T voorts voor gekozen om, in afwijking van de $\mathrm{Mw}$, 'op enkele punten een meer formalistische benadering te hanteren'. ${ }^{23}$ Dit heeft geleid tot de formulering in artikel 3 lid 2 van een aantal zogeheten per se-verboden. Per severboden (dus onafhankelijk van de vraag of de mededinging daadwerkelijk (merkbaar) wordt beperkt) zijn, grotendeels in navolging van artikel 101 VWEU, overeenkomsten, besluiten en onderling afgestemde feitelijke gedragingen die 'bestaan uit, direct of indirect:

a. het bepalen van verkoopprijzen of andere verkoopvoorwaarden;

b. het bepalen van inschrijfprijzen of andere biedingsvoorwaarden in geval van aanbestedingen;

c. het beperken of controleren van productie of afzet, waaronder gezamenlijke leveringsweigering;

d. het verdelen van markten.'

De Nederlandse wetgever heeft er destijds juist voor gekozen de voorbeelden van overeenkomsten en gedragingen die in ieder geval onder het kartelverbod van artikel 101 lid 1 VWEU vallen, niet over te nemen 'omdat het niet zinvol is voorbeelden in de wettekst te noemen'. ${ }^{24}$ Dat de Curaçaose wetgever op dit punt een andere keuze heeft gemaakt blijkt te zijn ingegeven door een behoefte aan 'verhoging van de rechtszekerheid voor justitiabelen en tegemoetkoming aan de met beperkte middelen uitgeruste autoriteit'. ${ }^{25}$ Het is evenwel de

21. Zie B.J. Drijber, 'Boekbespreking: Anna Gerbrandy, Convergentie in het mededingingsrecht', M\&M 2011/1, p. 39: '(D)e verplichting om in vrijwel elke zaak van betekenis artikel 101 of 102 VWEU toe te passen naast het nationale mededingingsrecht dwingt de NMa (en de bestuursrechter) feitelijk tot volledige convergentie.'

22. Zie ook r.o. 3.3.2 van HR 14 juli 2017, ECLI:NL:HR:2017:1354: 'Art. 6 lid $1 \mathrm{Mw}$ verbiedt onder meer besluiten van ondernemersverenigingen die ertoe strekken of ten gevolge hebben dat de mededinging op de Nederlandse markt of een deel daarvan wordt verhinderd, beperkt of vervalst. Deze bepaling is geënt op (het huidige) art. 101 VWEU. Bij de uitleg van eerstgenoemde bepaling dient dan ook zo veel mogelijk aansluiting te worden gezocht bij de uitleg van (thans) art. 101 VWEU in de rechtspraak van het HvJEU (vgl. HR 14 oktober 2005, ECLI:NL:HR: 2005:AT5542; HR 24 januari 2014, ECLI:NL:HR:2014:149, NJ 2016/489).' Zie nader de noot van Mok onder HvJ EU 13 december 2012, zaak C-226/11, Expedia, NJ 2013/253 en E.F. van Hasselt, H.E. Urlus en A. Baars, 'HvJ EU Expedia en de mededingingsrechtelijke merkbaarheid', M\&M 2013/4, p. 124. Zie ook Kamerstukken // 1995/96, 24707, nr. 3, p. 10 e.v., alwaar het 'niet strenger en niet soepeler'-criterium is opgenomen. Zie ook noot 12

23. MvT, Staten van Curaçao, zitting 2014/15, Landsverordening houdende vaststelling van de Landsverordening inzake concurrentie, nr. 3, p. 7-8.

24. Kamerstukken I/ 1995/96, 24 707, nr. 3 (MvT), p. 61.

25. MvT, Staten van Curaçao, zitting 2014/15, Landsverordening houdende vaststelling van de Landsverordening inzake concurrentie, nr. 3, p. 40. vraag of de rechtszekerheid wel zo erg wordt verhoogd door deze voorbeelden in de Landsverordening op te nemen, aangezien de onder a-d genoemde voorbeelden de nodige onscherpe begrippen en termen bevatten, die (niet vastomlijnd zijn, maar) steeds een (nadere) concretisering behoeven om op een gegeven casus te kunnen worden toegepast. Dit geldt in het bijzonder voor contextgevoelige termen als 'leveringsweigering' en 'het verdelen van markten'. Voor de justitiabelen, maar ook voor de toepasser van het prille Curaçaose mededingingsrecht zal niet steeds aanstonds duidelijk zijn of een bepaalde geconstateerde handelwijze onder de reikwijdte van de onder a-d genoemde per se-verboden valt. Het lijkt dan ook onontkoombaar dat ook bij de toepassing van de onder a-d genoemde termen en begrippen de specifieke omstandigheden van het geval steeds in ogenschouw zullen moeten worden genomen. Dat het hier, zoals de MvT stelt, om 'hard and fast rules'26 zou gaan, waarbij kan worden 'geabstraheerd van feitelijke (...) omstandigheden' ${ }^{27}$ kan mijns inziens niet worden volgehouden.

\section{Bagateluitzondering}

De in artikel 3.2 van de Landsverordening Concurrentie opgenomen bagatelregeling is eenvoudiger van opzet dan zijn Nederlandse pendant in de Mw en kent slechts een marktaandeelgerelateerde uitzondering. Het gekozen (hoge) percentage van 30 procent is blijkens de MvT ingegeven door redenen van doelmatigheid en passendheid in de Curaçaose context. Wat het eerste betreft: de FTAC heeft, zo lees ik de MvT, slechts beperkte capaciteit tot onderzoek en handhaving en zou, gegeven de plicht om op aanvraag 'andere dan per se verboden kartelafspraken boven de 30\%-grens te toetsen op mogelijke individuele ontheffing van het kartelverbod', met een lagere grens dan de gekozen 30 procent mogelijk tegen een probleem van onvoldoende capaciteit aanlopen. Daarnaast is de ruime vrijstelling volgens de Curaçaose wetgever een uitvloeisel van het gegeven dat 'in een kleine eilandeconomie zoals die van Curaçao de minimum efficiënte schaal soms kan dwingen de concurrentie voor een groot deel te beperken teneinde de noodzakelijke efficiëntievoordelen te behalen'. 28

Wat dit tweede argument voor de gehanteerde hoge bagatelgrens betreft: het is goed te zien dat de Curaçaose wetgever zich realiseert dat de bijzondere omstandigheden van kleine (eiland)economieën, als die van Curaçao, op het gebied van vraag en aanbod nopen tot 'maatwerk' op het gebied van regulering van de mededinging. In dergelijke economieën geldt nu eenmaal dat 'standard notions of competition may not work'. ${ }^{29}$ Dat door de Curaçaose wetgever een andere methodiek voor het bepalen van bagateluitzonderingen is gevolgd dan in

26. MvT, Staten van Curaçao, zitting 2014/15, Landsverordening houdende vaststelling van de Landsverordening inzake concurrentie, nr. 3, p. 8.

27. MvT, Staten van Curaçao, zitting 2014/15, Landsverordening houdende vaststelling van de Landsverordening inzake concurrentie, nr. 3, p. 40.

28. MvT, Staten van Curaçao, zitting 2014/15, Landsverordening houdende vaststelling van de Landsverordening inzake concurrentie, nr. 3, p. 8.

29. Ransom 1978, p. 113. 
Nederland, is daarom op zichzelf begrijpelijk en toe te juichen. Het ware echter te prefereren geweest indien in de MvT genoegzaam inzicht zou zijn geboden in de achtergronden en beweegredenen voor de keuze om juist het percentage van 30 procent te hanteren en niet een ander (hoger dan wel lager) percentage of alternatieve wijze van bepalen van de bagatelgrens. De verwijzing in de MvT naar 'mededingingsliteratuur', waaruit zou volgen dat

'ondernemingen die alleen of gezamenlijk over minder dan $30 \%$ van het marktaandeel op de betreffende markt beschikken, normaliter niet in staat zijn om hun positie op de markt in economische zin te misbruiken. Slechts in zeer uitzonderlijke situaties zou het nodig kunnen zijn om onderzoek te doen naar mogelijk mededingingbeperkend gedrag door ondernemingen met een lager (gezamenlijk) marktaandeel dan $30 \%$. ${ }^{30}$

overtuigt mijns inziens niet, enerzijds omdat de situatie op Curaçao als kleine insulaire economie vermoedelijk een andere ${ }^{31}$ is dan in de gebruikelijke Europese en Angelsaksische mededingingsrechtelijke literatuur wordt besproken en anderzijds omdat de bagateluitzondering van artikel 3.2 betrekking heeft op het kartelverbod en niet op marktmisbruik, ${ }^{32}$ welk fenomeen in Hoofdstuk 4 van de Landsverordening regeling vindt.

Door dit gebrek aan inzicht in de passendheid van de gekozen bagatelgrens valt moeilijk (zonder de beschikking te hebben over verificatoire gegevens ten aanzien van de werking en het functioneren van de Curaçaose economie) vast te stellen of de doelstellingen van de Curaçaose wetgever met de invoering van de Landsverordening met de gekozen bagatelgrens optimaal gediend worden.

Meerdere afzonderlijke onderling afgestemde feitelijke gedragingen

Op een wijze, vergelijkbaar met artikel 7 lid $3 \mathrm{Mw}$ bepaalt het tweede lid van artikel 3.2 van de Landsverordening dat indien meerdere afzonderlijke overeenkomsten tussen een onderneming of een ondernemersvereniging en twee of meer andere ondernemingen, dezelfde strekking hebben, deze overeenkomsten voor de toepassing van het eerste lid tezamen worden beschouwd als één overeenkomst. Artikel 3.2 voegt daar aan toe dat hetzelfde geldt voor 'afzonderlijke onderling afgestemde feitelijke gedragingen van een onderneming met twee of meer andere ondernemingen, die dezelfde

30. MvT, Staten van Curaçao, zitting 2014/15, Landsverordening houdende vaststelling van de Landsverordening inzake concurrentie, nr. 3, p. 14.

31. Mij lijkt in elk geval niet ondenkbaar dat in kleine insulaire economieën als die van Curaçao ook kartelafspraken door partijen met een (gezamenlijk) marktaandeel van onder de 30 procent al een reële verstoring van de mededinging tot gevolg zouden kunnen hebben. Of naar die mogelijkheid in 2011 (zie ook hiervoor) onderzoek is gedaan, is mij niet bekend.

32. Dit laat overigens onverlet dat ook bij concurrentiebeperkende afspraken een zekere marktmacht noodzakelijk is om de afspraken effectief de concurrentie te kunnen laten beperken. strekking hebben'. Deze gedragingen worden voor de toepassing van het eerste lid van artikel 3.2 eveneens tezamen beschouwd 'als één onderling afgestemde feitelijke gedraging.'

\section{Ontheffing kartelverbod}

In Nederland is met de invoering van artikel 6 lid $3 \mathrm{Mw}$ de mogelijkheid komen te vervallen om een ontheffing van het kartelverbod te vragen. Als gevolg hiervan zijn Nederlandse ondernemingen thans genoodzaakt zelf te beoordelen of hun overeenkomsten, besluiten of gedragingen een eventuele toetsing aan artikel 101 lid 3 VWEU of artikel 6 lid $3 \mathrm{Mw}$ kunnen doorstaan. ${ }^{33}$ Artikel 3.5 van de Landsverordening schrijft voor dat voor ontheffing van het kartelverbod een daartoe strekkende aanvraag bij de FTAC noodzakelijk is. ${ }^{34}$ De criteria voor toewijzing van zo'n ontheffing zijn (nagenoeg) dezelfde als vermeld in artikel 101 lid 3 VWEU en artikel 6 lid 3 Mw. Artikel 3.13 geeft aan dat ook bij landsbesluit door de regering bepaalde categorieën overeenkomsten, besluiten en gedragingen op grond van dezelfde criteria van de werking van het kartelverbod kunnen worden uitgezonderd.

Misbruik van een economische machtspositie Hoofdstuk 4 van de Landsverordening Concurrentie regelt de situatie dat misbruik van een economische machtspositie wordt gemaakt. Artikel 4.1 lid 1 is vrijwel gelijkluidend aan artikel 24 lid $1 \mathrm{Mw}$, met dien verstande dat de Curaçaose wetgever ervoor heeft gekozen in lid 2 de in artikel 102 VWEU genoemde voorbeelden wel op te nemen. Verschil in betekenis levert dit echter niet op. Anders dan in de Mw en het VWEU heeft de Curaçaose wetgever expliciet in de Landsverordening opgenomen dat van marktmisbruik geen sprake is indien de gedraging objectief kan worden gerechtvaardigd. $\mathrm{Nu}$ deze gedachte niet meer is dan een codificatie van geldend Europees en Nederlands mededingingsrecht, ${ }^{35}$ wijkt het Curaçaose recht ook op dit punt niet af van beide andere regelingen.

Wel anders ten opzichte van de Nederlandse en Europese regeling is dat de Landsverordening het in artikel 4.1 genoemde begrip 'machtspositie' nader omlijnt door in artikel 1.1 onder 1 aan te geven dat een machtspositie in ieder geval aanwezig is bij een marktaandeel van de betreffende onderneming van 60 procent of hoger. Blijkens de MvT is ook deze beslissing ingegeven door behoefte aan rechtszekerheid, maar daartegen kunnen mutatis mutandis dezelfde bezwaren worden aangevoerd als hiervoor al genoemd: de keuze om juist het percentage van 60 procent te hanteren en geen ander (hoger dan wel lager $)^{36}$ percentage of een alternatieve wijze van bepalen van een machtspositie wordt in de MvT mijns

33. Aldus P.J. Slot, T\&C Mededingingswet, commentaar op artikel $6 \mathrm{Mw}$, aant. 10.

34. Het betreffende aanvraagformulier is te vinden op <http://ftac.cw/ onderwerpen/ontheffing-kartelverbod/>.

35. Zie onder meer E.J. Zippro, Privaatrechtelijke handhaving van mededingingsrecht (diss. Leiden), Deventer: Kluwer 2008, p. 101-102.

36. Zie ook Zippro 2008, p. 90. 
inziens niet (voldoende) duidelijk gemaakt en verantwoord. ${ }^{37}$

Artikel 4.2 beschrijft vervolgens welk arsenaal de FTAC tot haar beschikking heeft bij een geconstateerde machtspositie. Ongeacht de vraag of de marktpositie daadwerkelijk wordt misbruikt of niet, kan de FTAC reeds bij (een redelijk vermoeden van $)^{38}$ het enkele bestaan van een machtspositie één of meer van de volgende verplichtingen aan de betreffende onderneming opleggen:

a. de verplichting om door de FTAC te bepalen categorieën van informatie aan door de FTAC te bepalen categorieën van belanghebbenden op een door de FTAC te bepalen wijze bekend te maken;

b. de verplichting om bij de levering van door de FTAC te bepalen producten of diensten de afnemers van die producten dan wel diensten in gelijke gevallen gelijk te behandelen;

c. de verplichting om een door de FTAC te bepalen dienst of product los te leveren van andere diensten of producten;

d. de verplichting de kosten en opbrengsten van door de FTAC te bepalen diensten of producten die de onderneming aan zichzelf of aan zijn afnemers aanbiedt, te scheiden van die van de overige door de onderneming verrichte activiteiten en daartoe een gescheiden boekhouding te voeren overeenkomstig door de FTAC gegeven aanwijzingen;

e. de verplichting onder redelijke voorwaarden te voldoen aan elk redelijk verzoek van een onderneming tot het sluiten van een overeenkomst;

f. andere, bij landsbesluit, houdende algemene maatregelen, aangewezen verplichtingen.

Lid 2 van het artikel vermeldt dat de FTAC bij het opleggen van verplichtingen als bedoeld in het eerste lid de eisen van proportionaliteit in acht neemt. Blijkens de MvT betreft het hier preventieve maatregelen die de FTAC kan nemen ter voorkoming dat van een dominante marktpositie misbruik wordt gemaakt. Deze keuze voor het kunnen uitvoeren van preventieve maatregelen wordt in de MvT verdedigd door erop te wijzen dat op Curaçao - vergeleken met Europese economieën - een grotere kans bestaat op machtsposities en misbruik daarvan. ${ }^{39} \mathrm{Nog}$ afgezien van het feit dat dit standpunt in de MvT geen (afdoende) onderbouwing vindt, lijkt me

37. Zulks mede in het licht van het feit dat in de MvT (p. 31) wordt erkend dat Curaçao op dit punt afwijkt 'van de Europese rechtspraak'.

38. Art. 4.4 van de Landsverordening bepaalt: 'Indien de FTAC het vermoeden heeft dat sprake is van een in artikel 4.2, eerste lid, eerste zinsnede, bedoelde machtspositie, kan zij in spoedeisende gevallen vooruitlopen op de toepassing van artikel 4.2 en de desbetreffende onderneming of ondernemingen bij beschikking een of meer van de verplichtingen opleggen, genoemd in artikel 4.2, eerste lid.'

39. MvT, Staten van Curaçao, zitting 2014/15, Landsverordening houdende vaststelling van de Landsverordening inzake concurrentie, nr. 3, p. 43. deze mogelijkheid van een 'pre-emptive strike'40 door de toezichthouder wel erg ver gaan. Met name de mogelijkheid van het opleggen van een verplichting om met derden contracten te sluiten, is bepaald verstrekkend, mede in het licht van het ook op Curaçao vigerende beginsel van contractsvrijheid. Ik zou menen dat waar misbruik van een machtspositie kennelijk niet aan de orde is en niet anderszins mededingingsbeperkend door de betreffende onderneming wordt gehandeld, de toezichthouder in beginsel geen taak (of bevoegdheden) hoort te hebben. In de woorden van Zippro: 'Het bezitten van een machtspositie vormt op zichzelf geen probleem en is niet verboden. ${ }^{41}$

\section{Concentratietoezicht}

Over Hoofdstuk 5 van de Landsverordening, dat regelt hoe met concentraties moet worden omgegaan, kan ik korter zijn. Evenals Hoofdstuk 5 van de Mw is de regeling geënt op de EG-concentratieverordening (Verordening (EG) nr. 139/2004, PbEU 2004, L 24/1). De regeling voorziet enkel in een meldplicht van concentraties. Een concentratie moet voorafgaande aan de totstandbrenging ervan worden gemeld bij de FTAC indien:

a. de gezamenlijke omzet van de betrokken ondernemingen in het voorafgaande kalenderjaar meer bedroeg dan NAf 125 miljoen waarvan door ten minste twee van de betrokken ondernemingen ieder ten minste NAf 15 miljoen in Curaçao is behaald, of;

b. de betrokken ondernemingen daardoor op één of meer relevante markten in Curaçao een marktaandeel van 30 procent of meer creëren of versterken.

De regeling kent derhalve zowel een tweetal omzetdrempels als een marktaandeeldrempel. ${ }^{42}$ De concentraties worden niet inhoudelijk door de FTAC getoetst en kunnen evenmin door de FTAC worden tegengehouden of geblokkeerd, aldus de MvT. ${ }^{43}$ De regeling zal eerst in de huidige vorm worden uitgetest, waarna bij de hiervoor al genoemde evaluatie van de Landsverordening over vijf jaar opnieuw zal worden bezien of inhoudelijk concentratietoezicht (en, neem ik aan, invoering van een met de Nederlandse regeling vergelijkbaar vergunningensysteem) toch gewenst en geboden is.

40. Deze mogelijkheid om ex ante op te treden lijkt geïnspireerd te zijn op de bevoegdheden van de NZa in geval van aanmerkelijke marktmacht in het kader van de Wet marktordening gezondheidszorg. De MvT bij de Landsverordening geeft helaas geen duidelijkheid over de vraag of resp. in hoeverre de keuze voor het creëren van ex ante bevoegdheden ook dan wel juist (bijvoorbeeld vanwege de specifieke omstandigheden van zijn kleine, insulaire economie) op Curaçao gerechtvaardigd en zin$\mathrm{vol}$ is.

41. Zippro 2008, p. 84

42. De MvT (p. 44) meldt hierover: 'Mede met het oog op deze evaluatie [de in art. 10.3 van de Landsverordening genoemde evaluatie van de wet na vijf jaar, PSB] is ervoor gekozen naast omzetdrempels zoals gehanteerd in onder meer het Europese concentratietoezicht, tevens een marktaandeeldrempel te hanteren.'

43. MvT, Staten van Curaçao, zitting 2014/15, Landsverordening houdende vaststelling van de Landsverordening inzake concurrentie, nr. 3, p. 44. 


\section{Publiek- en privaatrechtelijke handhaving}

Publiekrechtelijke handhaving

Artikel 6.1 van de Landsverordening Concurrentie bepaalt dat de FTAC zowel toezicht houdt op de naleving daarvan als onderzoek kan doen. Hoewel de MvT zich over de doelstellingen van de publiekrechtelijke handhaving van het in de Landsverordening opgenomen mededingingsrecht niet expliciet uitlaat, moet aangenomen worden dat deze voor een belangrijk deel in het teken staat van het voorkomen van mededingingsbeperkend handelen. Dit komt wellicht het sterkst tot uitdrukking in het hiervoor behandelde artikel 4.2 van de Landsverordening, dat de mogelijkheid schept om bij een geconstateerde machtspositie (soms verstrekkende) preventieve maatregelen jegens de betreffende onderneming te treffen. Ook de in artikel 6.1 van de Landsverordening verankerde (en elders in de regeling nader uitgewerkte) mogelijkheid om (zo nodig met behulp van de 'sterke arm') onderzoek te doen staat denkelijk deels in de sleutel van preventie (en afschrikking). Daarnaast heeft de publiekrechtelijke handhaving van het Curaçaose mededingingsrecht evident ook (waar het gaat om de mogelijkheid tot het opleggen van boetes) een punitief, bestraffend aspect.

De FTAC beschikt, in navolging van haar Nederlandse tegenhanger, de Autoriteit Consument \& Markt, over een ruim arsenaal om geconstateerde overtredingen van de mededingingsregels tegen te gaan. De FTAC kan bij geconstateerde schendingen van artikel 3.1 lid 1 of artikel 4.1 lid 1 blijkens artikel 7.1 van de Landsverordening

a. een bindende aanwijzing tot naleving van de Landsverordening opleggen;

b. een bestuurlijke boete opleggen, indien de natuurlijke persoon of rechtspersoon voor een vergelijkbare overtreding reeds eerder een bindende aanwijzing is opgelegd;

c. een last onder dwangsom opleggen, indien de natuurlijke persoon of rechtspersoon voor een vergelijkbare overtreding reeds eerder een bindende aanwijzing is opgelegd.

De MvT licht toe dat, in geval van overtreding van andere dan de in artikel 3.1 lid 2 genoemde per se verboden kartelgedragingen en gedragingen in strijd met preventief opgelegde verplichtingen bij machtsposities (zie art. 4.2 lid 1 en 4.4 lid 1 van de Landsverordening), een bestuurlijke sanctie alleen op haar plaats is indien de natuurlijke persoon of rechtspersoon voor een vergelijkbare overtreding reeds eerder een bindende aanwijzing ('zelf geen bestuurlijke sanctie') is opgelegd (en deze dus vooraf al is 'gewaarschuwd'): 'De achtergrond daarvan is dat juist bij dergelijke overtredingen het nuttig is vooral te zorgen voor een verduidelijking van de (nog niet altijd even duidelijke) mededingingsrechtelijke norm' ${ }^{44}$

Deze handreiking aan de justitiabelen zal bij de hiervoor al genoemde evaluatie van de Landsverordening over vijf jaar opnieuw tegen het licht worden gehouden. Een dergelijke coulance is volgens de Curaçaose wetgever in geval van per se verboden kartelgedragingen en gedragingen in strijd met preventief opgelegde verplichtingen bij machtsposities niet nodig; in die gevallen kan een bestuurlijke boete of last onder dwangsom weI worden ingezet zonder dat eerst een bindende aanwijzing is opgelegd. Deze gedragingen zijn volgens de Curaçaose wetgever 'zo evident onrechtmatig' en de daarop van toepassing zijnde normen 'laten doorgaans (zo) weinig aan onzekerheid over, dat een voorafgaande bindende aanwijzing niet nodig of zelfs onwenselijk wordt geacht' Met name ten aanzien van de per se-verboden heb ik hier, als gezegd, mijn twijfels over: gelet op de betrekkelijke vaagheid van de in die verboden opgenomen termen en begrippen moet er rekening mee worden gehouden dat voor de justitiabelen (die aan de nieuwe regelgeving moeten wennen en hun gedrag hierop moeten aanpassen), maar ook voor de toepasser van het prille Curaçaose mededingingsrecht niet steeds aanstonds duidelijk zal zijn of een bepaalde geconstateerde handelwijze onder de reikwijdte van de onder a-d van artikel 3.1 lid 2 genoemde per se-verboden valt.

Op grond van artikel 8.6 van de Landsverordening heeft de FTAC te gelden als een bestuursorgaan in de zin van artikel 2 van de Landsverordening administratieve rechtspraak (Lar). ${ }^{45}$ De sancties die de FTAC kan opleggen zijn aan te merken als beschikkingen, waartegen bezwaar bij de FTAC en beroep bij de Curaçaose administratieve rechter openstaat. Genoemde Lar regeert derhalve de te volgen procedures van bezwaar en beroep. Het beperkte bestek van dit artikel laat helaas niet toe nader in te gaan op de bijzonderheden van die bestuursrechtelijke procedures, met name ten opzichte van het in de Nederlandse Algemene wet bestuursrecht (Awb) verankerde bestuursprocesrecht. ${ }^{46}$

\section{Privaatrechtelijke handhaving}

Overeenkomsten die in strijd zijn met artikel 3.1 van de Landsverordening Concurrentie zijn nietig, zo leert het derde lid van dit artikel. Die nietigheid kan, evenals in Nederland, voor de Curaçaose burgerlijke rechter worden ingeroepen. Het inroepen van civielrechtelijke nietigheid wordt ook wel defensieve privaatrechtelijke

44. MvT, Staten van Curaçao, zitting 2014/15, Landsverordening houdende vaststelling van de Landsverordening inzake concurrentie, nr. 3, p. 48.

45. P.B. 2001 , no. 79

46. Voor een recente studie over de Lar verwijs ik graag naar M.E.B. de Haseth, L.J.J. Rogier en J. Sybesma, Landsverordening administratieve rechtspraak Curaçao (SNAAR deel 26), Den Haag: Boom juridisch 2016 (2e geheel herziene druk). Voor een interessante en prikkelende beschouwing over het bestuursrecht in het Caribisch en Europees deel van het Koninkrijk zij op deze plaats verwezen naar S.E. Zijlstra, 'Naar een Landsverordening algemene regels van bestuursrecht? Beschouwingen over nut en noodzaak van een Awb voor Caribisch Nederland', Caribisch Juristenblad 2015 (4), p. 257 e.v. 
handhaving genoemd; men spreekt in dit kader wel van het 'schild' van de nietigheid. ${ }^{47}$

Daarnaast is er het 'zwaard' van de schadevergoeding oftewel de mogelijkheid tot offensieve privaatrechtelijke handhaving. ${ }^{48}$ Ook naar Curaçaos recht zal vanaf 1 september 2017 de mogelijkheid voor gedupeerden bestaan om bij geleden schade als gevolg van overtreding van het vanaf die datum van kracht zijnde kartelverbod tegen de betreffende onderneming een actie uit onrechtmatige daad (art. 6:162 Curaçaos Burgerlijk Wetboek (BW)) in te stellen. Ook in geval van misbruik door een onderneming van een economische machtspositie laat zich een dergelijke vordering heel wel denken. In beide gevallen is ook denkbaar dat een verbod wordt gevraagd tot het in de toekomst herhalen van schendingen van mededingingsrecht. Voorts kan gewezen worden op een mogelijke andere grondslag tot verkrijging van schadevergoeding, te weten de actie uit ongerechtvaardigde verrijking (art. 6:212 BW). Ook leerstukken als onverschuldigde betaling (art. 6:203 BW) en het wilsgebrek van de dwaling (art. 6:228 BW) kunnen denkelijk in de toekomst nuttige diensten bewijzen ter redres van nadeel dat door schendingen van het mededingingsrecht voor consumenten of ondernemingen is ontstaan. ${ }^{49}$

De privaatrechtelijke handhaving van mededingingsrecht staat in Nederland sinds een aantal jaren volop in de belangstelling, niet in de laatste plaats vanwege meerdere Europese initiatieven tot versterking van de mogelijkheden tot privaatrechtelijke handhaving van het mededingingsrecht. Daarvan kan met name worden genoemd Richtlijn 2014/104/EU van het Europees Parlement en de Raad van 26 november 2014, die inmiddels is geimplementeerd in Boek 6 van het Nederlands Burgerlijk Wetboek en het Wetboek van Burgerlijke Rechtsvordering (Implementatiewet richtlijn privaatrechtelijke handhaving mededingingsrecht). ${ }^{50}$ De tijd zal leren of ook op Curaçao de privaatrechtelijke handhaving 'van de grond zal komen'. Gezien het feit dat het civielrechtelijk arsenaal aan mogelijkheden op dat vlak op Curaçao niet wezenlijk anders of kleiner is dan in Nederland, is mijn verwachting evenwel dat ook de gedupeerde Curaçaose justitiabele na 1 september 2017 de weg naar de civiele rechter zal te weten te vinden, indien hij als gevolg van een schending van het mededingingsrecht in zijn vermogensrechtelijke belangen is aangetast.

47. Zippro 2008, p. 3

48. Zippro 2008, p. 3.

49. Het beperkte bestek van dit artikel laat helaas niet toe nader in te gaan op de mogelijkheden tot privaatrechtelijke handhaving van Curaçaos mededingingsrecht. Voor twee diepgravende studies naar privaatrechtelijke handhaving van Nederlands mededingingsrecht zij verwezen naar E.J. Zippro, Privaatrechtelijke handhaving van mededingingsrecht (diss. Leiden), Deventer: Kluwer 2008 en I.P.M. Ligteringen, Privaatrechtelijke gevolgen van een schending van het mededingingsrecht (Onderneming en Recht, nr. 96), Deventer: Wolters Kluwer 2016. Zie ook onder (veel) meer: E.D. Glerum-van Aalst en S.R. Brand, 'Privaatrechtelijke handhaving van het mededingingsrecht: recente ontwikkelingen', MvV 2014/9.

50. Zie nader <http://njb.nl/wetgeving/staatsbladen/privaatrechtelijkehandhaving-mededingingsrecht.20043.lynkx>.

\section{Slot}

In deze bijdrage werd een introductie gegeven van het Curaçaose mededingingsrecht, zoals dit per 1 september 2017 van kracht is geworden. Allereerst werd stilgestaan bij de achtergronden voor invoering van de Landsverordening Concurrentie op Curaçao en de vraag in hoeverre kleinere jurisdicties als die van Curaçao (überhaupt) regels nodig hebben die de economische mededinging reguleren en aan banden leggen. Geconstateerd werd dat de bijzondere omstandigheden van kleine (eiland)economieën als die van Curaçao wat vraag en aanbod betreft nopen tot 'maatwerk' op het gebied van regulering van de mededinging. In dergelijke economieen geldt nu eenmaal dat 'standard notions of competition may not work'. ${ }^{51}$ Betoogd werd dat de op Curaçao ontplooide initiatieven tot mededingingswetgeving en de oprichting van een mededingingsautoriteit die toezicht houdt op de naleving van die wetgeving past binnen een brede tendens in de Caribische regio om voor buitenlandse ondernemingen een aantrekkelijk(er) investeringsklimaat te scheppen en die regio in sync te brengen met de wereldwijd en ook in de regio sterk toenemende behoefte aan open en transparante (handels)markten, die gekenmerkt worden door een vrije en onbelemmerde mededinging.

Vervolgens werd de Landsverordening Concurrentie op de belangrijkste punten vergeleken met de Nederlandse Mw. Geconstateerd werd dat, naast veel overeenkomstigheid, ook een aantal verschillen tussen beide regelingen bestaat. Zo viel op het gebruik van het woord 'merkbaar' in de tekst van artikel 3.1 van de Landsverordening, waarmee door de Curaçaose wetgever, wellicht onbedoeld, de suggestie wordt gewekt dat bij strekkingsbeperkingen die onder de scope van het Curaçaose mededingingsrecht vallen, de merkbaarheid wel nog afzonderlijk getoetst zou moeten worden. Voorts vormde een opvallend verschil met de Mw het in de Landsverordening voorkomen van zogeheten per se-verboden. Betoogd werd dat, hoewel de keus daarvoor is ingegeven door een behoefte aan 'verhoging van de rechtszekerheid voor justitiabelen en tegemoetkoming aan de met beperkte middelen uitgeruste autoriteit', de vraag zich laat stellen in hoeverre de rechtszekerheid met de opname in de regeling van genoemde per se-verboden werkelijk gediend is. Van echte 'hard and fast rules', waarbij kan worden 'geabstraheerd van feitelijke (...) omstandigheden', lijkt namelijk geen sprake te zijn.

De in artikel 3.2 van de Landsverordening Concurrentie opgenomen bagatelregeling bleek eenvoudiger van opzet dan haar Nederlandse pendant in de Mw en slechts een marktaandeelgerelateerde uitzondering te kennen. Over het door de Curaçaose wetgever gekozen (hoge) percentage van 30 procent werd opgemerkt dat de MvT weinig inzicht biedt in de achtergronden en beweegredenen voor de keuze om juist het percentage van 30 procent te hanteren en geen ander (hoger dan wel lager) percentage

51. Ransom 1978, p. 113 
of een alternatieve wijze van bepalen van de bagatelgrens. Opgemerkt werd dat ditzelfde bezwaar mutatis mutandis kan worden aangevoerd tegen de beslissing om het in artikel 4.1 genoemde begrip 'machtspositie' nader te omlijnen door in artikel 1.1 onder 1 van de regeling aan te geven dat een machtspositie in ieder geval aanwezig is bij een marktaandeel van de betreffende onderneming van 60 procent of hoger.

Over de concentratieregeling in de Landsverordening werd opgemerkt dat deze in grote lijnen vergelijkbaar is met de Nederlandse en Europese regeling, maar niet voorziet in een mogelijkheid tot inhoudelijke toetsing door de FTAC of de mogelijkheid een concentratie te blokkeren. Deze regeling zal over vijf jaar worden geëvalueerd.

Tot slot werd de publiek- en privaatrechtelijke handhaving van het Curaçaose mededingingsrecht kort besproken. Op grond van artikel 8.6 van de Landsverordening heeft de FTAC te gelden als een bestuursorgaan in de zin van artikel 2 van de Landsverordening administratieve rechtspraak (Lar). De (al dan niet preventieve) sancties die de FTAC kan opleggen zijn aan te merken als beschikkingen, waartegen bezwaar bij de FTAC en beroep bij de Curaçaose administratieve rechter openstaat. Genoemde Lar regeert derhalve de te volgen procedures van bezwaar en beroep. Ook de belangrijkste mogelijkheden tot privaatrechtelijke handhaving werden kort aangestipt. De verwachting werd uitgesproken dat, nu de mogelijkheden op dat vlak op Curaçao niet wezenlijk anders of kleiner zijn dan in Nederland, ook de gedupeerde Curaçaose justitiabele na 1 september 2017 de weg naar de civiele rechter zal te weten te vinden, indien hij als gevolg van schending van het mededingingsrecht in zijn vermogensrechtelijke belangen is aangetast. 